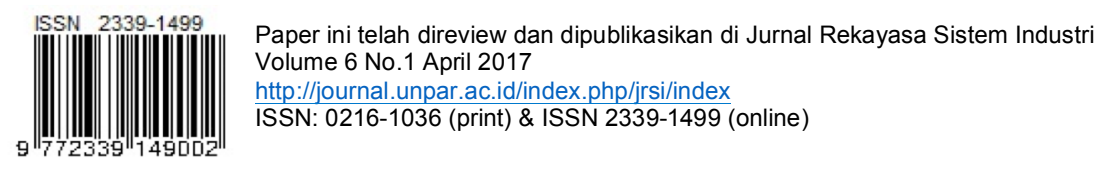

\title{
Monitoring dan Evaluasi IKM Tekstil dan Produk Tekstil di Kota Bandung
}

\author{
Rizki Wahyuniardi ${ }^{1}$, Riza Fathoni ${ }^{2}$, Sidik Nurjaman ${ }^{3}$, Wanda Gusdya ${ }^{4}$ \\ ${ }^{1,2,3)}$ Program Studi Teknik Industri ${ }^{4)}$ Program Studi Teknik Informatika \\ Fakultas Teknik, Universitas Pasundan \\ email : rizki.wahyuniardi@unpas.ac.id
}

\begin{abstract}
Small and Medium Enterprise (SME) as a part of the national industrial sector has a critical influence in developing economic, social and political state of Indonesia. Therefore, the government has issued many policies, programs, and activities to enhance the development of SMEs. The absence of an online information system that shows the development of the SME cause the government has difficulty in overseeing the development of SMEs. Difficulties experienced by the government due to lack of information also in line with Law No. 3 of 2014 on Industry, precisely on Article 64 which stated that the industry is obligated to submit industry data that are accurate, complete, and timely periodically to the Minister, governors and regents/mayors. Therefore, the industry, in particular Small and Medium Enterprise (SME), requires a web-based information system that will be a tool that can be used by industry to facilitate the reporting of industrial activities. Therefore, this research aimed to develop a webbased information system for SMEs Sentra Textiles and textile products (TPT) in West Java. The system will contain information about the condition and position of SMEs Sentra Textiles and textile products (TPT) in Bandung, West Java. In addition to preparing an information system, this research will conduct an analysis of the current condition of SMEs to be taken into consideration in making the SME development strategy.
\end{abstract}

Keywords: evaluation, monitoring, center, information systems

\begin{abstract}
Abstrak
Industri Kecil dan Menengah (IKM) sebagai bagian dari sektor industri nasional memiliki pengaruh yang penting di dalam mengembangkan ekonomi, sosial, maupun politik negara Indonesia. Oleh karena itu, pemerintah telah mengeluarkan banyak kebijakan, program, maupun kegiatan untuk meningkatkan pembangunan IKM. Adapun ketiadaan sistem informasi yang secara online menunjukkan perkembangan IKM menyebabkan pemerintah kesulitan di dalam mengawasi perkembangan IKM. Kesulitan yang dirasakan oleh pemerintah dikarenakan tidak adanya sistem informasi juga sejalan dengan Undang-Undang No. 3 Tahun 2014 tentang Perindustrian, tepatnya pada Pasal 64 yang menyampaikan bahwa industri wajib menyampaikan data industri yang akurat, lengkap, dan tepat waktu secara berkala kepada Menteri, gubernur, dan bupati/walikota. Oleh karenanya, industri, khususnya Industri Kecil dan Menengah (IKM), membutuhkan sistem informasi berbasis web yang akan menjadi sarana yang dapat dipergunakan oleh industri dalam mempermudah pelaporan kegiatan industrinya. Maka dari itu, penelitian ini bertujuan untuk menyusun sebuah sistem informasi berbasis web bagi Sentra IKM Tekstil dan Produk Tekstil (TPT) di Jawa Barat. Sistem informasi ini akan berisi tentang kondisi dan posisi Sentra IKM Tekstil dan Produk Tekstil (TPT) di Bandung Jawa Barat. Selain menyusun sebuah sistem informasi, penelitian ini akan melakukan analisis terhadap kondisi IKM saat ini agar dapat menjadi pertimbangan di dalam pembuatan strategi pengembangannya.
\end{abstract}

Kata kunci : evaluasi, monitoring, sentra, sistem informasi

\section{Pendahuluan}

Pembangunan industri merupakan bagian dari pembangunan nasional, oleh sebab itu pembangunan industri harus diarahkan untuk menjadikan industri mampu memberikan sumbangan berarti bagi pembangunan ekonomi, sosial dan politik Indonesia. Pembangunan sektor industri, tidak hanya ditujukan untuk mengatasi permasalahan dan kelemahan di sektor industri yang disebabkan oleh melem ahnya daya saing dan krisis global yang melanda dunia saat ini saja, melainkan juga harus mampu turut mengatasi permasalahan nasional, serta meletakkan dasar-dasar membangun industri andalan masa depan.

Pengembangan IKM oleh Kementerian Perindustrian sebagai Pembina sektor industri di Indonesia telah banyak dilakukan dengan berbagai kebijakan, program maupun kegiatan. Seluruh kegiatan itu dimaksudkan untuk mencapai Visi Pembangunan Industri Nasional Jangka 
Panjang (2025) yaitu Membawa Indonesia pada tahun 2025 untuk menjadi Negara Industri Tangguh Dunia yang bercirikan :

1. Industri kelas dunia;

2. PDB sektor Industri yang seimbang antara Pulau Jawa dan Luar Jawa;

3. Teknologi menjadi ujung tombak pengembangan produk dan penciptaan pasar.

Dalam mewujudkan visi tersebut, salah satu kebijakan yang dibuat oleh pemerintah adalah Peraturan Presiden Nomor 28 tahun 2008 tentang Kebijakan Industri Nasional. Dalam peraturan ini ditetapkan Bangun Industri Nasional tahun 2025. Dalam Bangun Industri Nasional tahun 2025, industri terbagi dalam klaster industri prioritas yang terdiri atas sekelompok industri. Kelompok-kelompok tersebut terdiri atas 6 (enam) basis dengan total 35 klaster industri. Di tahun 2009, pemerintah melalui Kementerian Perindustrian telah menyelesaikan 35 kebijakan berbentuk Peraturan Menteri yang membahas 35 klaster industri tersebut. Namun sayangnya, belum ada sistem informasi yang secara on-line mampu memperlihatkan perkembangan masingmasing klaster tersebut terkait pembinaan yang telah dilakukan sebelumnya. Kebutuhan ini juga relevan dengan terbitnya Undang-Undang No. 3 Tahun 2014 tentang Perindustrian. Pada Pasal 64 disampaikan bahwa industri wajib menyampaikan Data Industri yang akurat, lengkap, dan tepat waktu secara berkala kepada Menteri, Gubernur, dan Bupati/Walikota. Oleh karena itu, diperlukan suatu penelitian yang mampu menghasilkan perangkat lunak yang dapat mempermudah para pengambil kebijakan memperoleh data aktual, menganalis dan mengambil langkah pembinaan yang diperlukan di masa-masa mendatang, serta membantu industri, khususnya Industri Kecil Menengah, dalam pelaporan kegiatan industrinya .

Adapun tujuan dari penelitian ini adalah (1) Identifikasi jumlah IKM yang ada di Sentra Industri Rajut Binong Jati, (2) Penilaian Klasifikasi IKM Tekstil dan Produk
Tekstil (TPT) di Sentra Industri Rajut Binong Jati, dan (3) Pembuatan Sistem Informasi berbasis web. Hasil dari penelitian ini akan digunakan sebagai basis pelaksanaan kegiatan selanjutnya di sentra-sentra IKM Industri TPT lainnya di Prov. Jawa Barat yang tersebar di 5 (lima) kabupaten lain yang ada di Provinsi Jawa Barat dan memiliki aktivitas Industri TPT yaitu di Kab. Bandung, Kab. Bandung Barat, Kab. Tasikmalaya, Kab. Garut dan Kota Cirebon.

\section{Metode Penelitian}

Bagian ini akan membahas langkahlangkah yang dilakukan dalam penelitian ini. Proses penelitian dimulai dari studi pendahuluan, penetapan tujuan penelitian, penyusunan metodologi dan rencana survey, pelaksanaan survey pendahuluan, rekapitulasi data survey pendahuluan, survey lanjutan, pengolahan data, dilanjutkan dengan analisis data, serta pembuatan kesimpulan. Langkah-langkah penelitian secara rinci dapat dilihat pada Gambar 1.

\section{Studi Pendahuluan}

Bagian ini dilakukan dengan mencari literature yang terkait dengan permasalahan. Adapun literatur yang dicari adalah literature mengenai evaluasi, sistem informasi, software development life cycle (SDLC), metode analisa dan disain berbasis objek, analisis GAP, serta analisis SWOT. Pada bagian ini juga ditetapkan secara lebih rinci mengenai tujuan penelitian yang dilakukan.

\section{Perencanaan dan Penyusunan Survei Kuesioner Penelitian}

Survei dilakukan secara menyeluruh (populasi) untuk memperoleh gambaran lengkap IKM yang ada di lokasi penelitian. Survei akan dilakukan oleh tenaga surveyor yang disebar ke seluruh lokasi penelitian. Untuk menjaga validitas data yang akan dikumpulkan, maka survei akan dilakukan dalam 2 (dua) tahapan. Tahapan pertama dilakukan untuk mengumpulkan data-data IKM yang ada dan bersedia 
untuk disurvei. Hasil survei pertama ini akan dikonfirmasikan kepada pihak yang berwenang untuk mendapatkan validitas data. Jika data dianggap masih kurang valid, maka dilakukan tahapan survei kedua untuk melengkapi data-data yang ada.

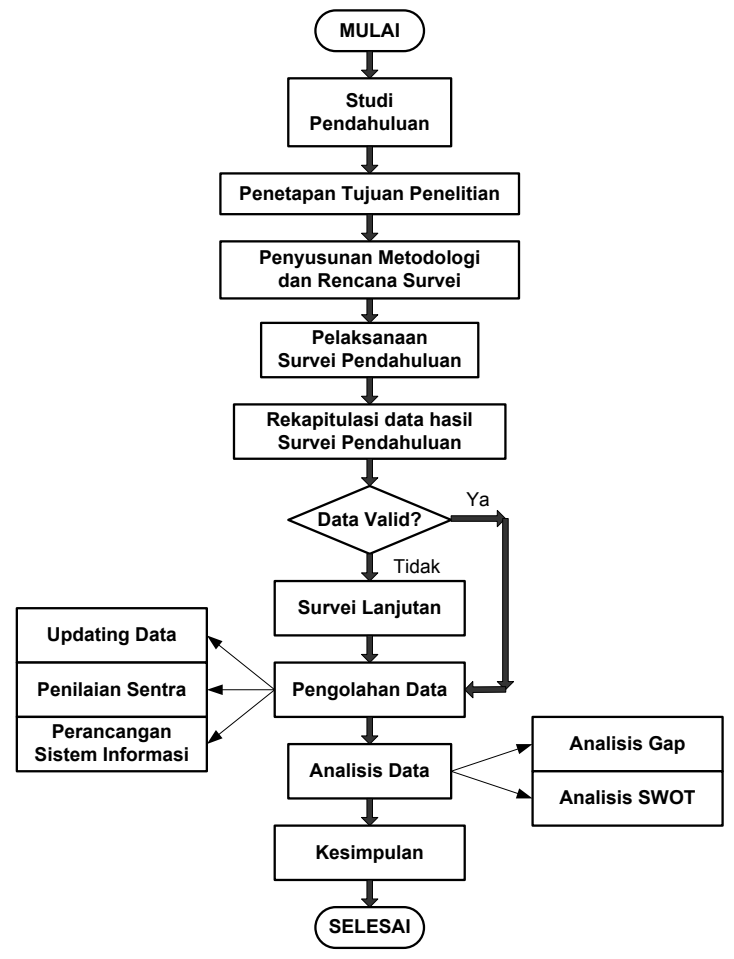

Gambar 1. Flowchart metode penelitian

Kuesioner disusun untuk memperoleh datadata aktual dari IKM. Variabel-variabel yang akan digunakan dalam kuesioner ini meliputi :

1. Data Induk berupa nama perusahaan, sentra, nama pemilik perusahaan, contact person, tahun berdiri, dan alamat perusahaan.

2. Data Kondisi Perusahaan berupa jumlah tenaga kerja, dilanjutkan dengan jenis, kapasitas dan nilai produksi per tahun, selanjutnya adalah penjualan per tahun, jenis dan kebutuhan bahan baku per tahun, mesin dan peralatan, pembinaan yang pernah diterima, permasalahan yang dihadapi, serta kebutuhan untuk pengembangan usaha.

\section{Pelaksanaan Survei}

Pelaksanaan survey terbagi menjadi dua, yaitu survey pendahuluan dan survey lanjutan. Survey pendahuluan dilakukan pertama kali. Pada bagian ini, peneliti melakukan kegiatan surat menyurat ke Dinas Perindustrian dan Perdagangan Prov. Jawa Barat dan Dinas Koperasi, UKM dan Perindustrian Kota Bandung. Surat menyurat yang dilakukan ini bertujuan untuk meminta izin dari pihak yang bersangkutan dan meminta data kondisi eksisting perkembangan IKM, khususnya Sentra Industri TPT Kab. Bandung, Kab. Bandung Barat, Kota Tasikamalaya, Kab. Garut dan Kota Cirebon.

Survei selanjutnya adalah survey lanjutan. Pada survey lanjutan, pemeriksaan kondisi eksisting perkembangan IKM langsung dilakukan ke IKM tersebut. Langkah ini digunakan untuk memastikan bahwa data yang digunakan dalam penelitian merupakan data yang actual. Setalah didapatkan data dari survey lanjutan, data ini kemudian digunakan untuk proses validasi. Pada proses validasi, data kondisi perkembangan IKM yang didapatkan dari survey pendahuluan dibandingkan dengan data kondisi perkembangan IKM yang didapatkan dari survey lanjutan.

\section{Pengolahan Data}

Pengolahan data yang dilakukan terbagi menjadi tiga, yaitu updating data IKM, penilaian sentra IKM, dan perancangan sistem informasi.

\section{Updating data IKM}

Setelah data hasil survei lanjutan terkumpul, maka dilakukan rekapitulasi jumlah IKM, tenaga kerja, dan data-data lainnya. Rekapitulasi ini akan digunakan sebagai bahan validasi bagi instansi terkait dengan membandingkannya dengan data yang dimiliki instansi.

\section{A. Penilaian sentra IKM}

Penilaian sentra dilakukan dengan mempergunakan form penilaian IKM dalam sentra yang tertera dalam Buku Petunjuk Teknis Penilaian, Klasifikasi dan Pembinaan Produk OVOP dari Kementerian Perindustrian (2012). Tujuan dari penilaian ini adalah mengetahui posisi sentra dalam pelaksanaan kegiatan industrinya. Penilaian dilakukan dengan memberikan nilai-nilai tertentu pada kondisi eksisting yang telah diketahui dari hasil survei. Dari penilaian ini akan diperoleh posisi sentra berdasarkan klasifikasi Bintang 1 hingga Bintang 5 sesuai hasil dari Form Penilaian Sentra. 


\section{B. Perancangan Sistem Informasi}

Dalam perancangan dan penyusunan sistem informasi berbasis web, metodologi yang paling tepat untuk digunakan adalah pendekatan pembangunan berbasis objek. Pendekatan yang tidak statis dan sangat dinamis ini merupakan metodologi yang paling tepat karena akan memudahkan pihak penyelenggara maupun pihak konsultan. Rational Unified Process (RUP) merupakan suatu metode rekayasa perangkat lunak yang dikembangkan dengan mengumpulkan berbagai best practices yang terdapat dalam industri pengembangan perangkat lunak. Ciri utama metode ini adalah menggunakan use-case driven dan pendekatan iteratif untuk siklus pengembangan perangkat lunak.

RUP ini menggunakan konsep object oriented, dengan aktifitas yang berfokus pada pengembangan model dengan menggunakan Unified Model Language (UML). RUP memiliki dua dimensi. Dimensi pertama yang digambarkan secara horizontal mewakili aspek-aspek dinamis dari pengembangan perangkat lunak. Aspek ini dijabarkan dalam tahapan pengembangan atau fase. Setiap fase akan memiliki suatu major milestone yang menandakan akhir dari awal dari phase selanjutnya. Setiap phase dapat berdiri dari satu beberapa iterasi. Dimensi ini terdiri atas Inception, Elaboration, Construction, dan Transition.

Dimensi kedua yang digambarkan secara vertikal mewakili aspek-aspek statis dari proses pengembangan perangkat lunak yang dikelompokkan ke dalam beberapa disiplin. Proses pengembangan perangkat lunak yang dijelaskan kedalam beberapa disiplin terdiri dari empat elemen penting, yakni who is doing, what, how dan when. Dimensi ini terdiri atas Business Modeling, Requirement, Analysis and Design, Implementation, Test, Deployment, Configuration dan Change Manegement, Project Management, Environtment.

\section{Analisis Data}

Analisis yang dilakukan terbagi menjadi dua, yaitu analisis GAP dan SWOT. Analisis SWOT dilakukan untuk mengetahui kelebihan, kekurangan, kekuatan, dan ancaman bagi sentra yang diteliti. Sedangkan analisis GAP dilakukan untuk mengetahui kesenjangan antara target dan kondisi eksisting. Analisis ini dilakukan setalah data yang telah dikumpulkan telah ditabulasi.

\section{Hasil dan Pembahasan}

\section{Hasil Pelaksanaan Survei}

Survei dilakukan pada wilayah fokus penelitian yaitu Sentra Industri Rajut Binong Jati yang berada di Kelurahan Binong Kecamatan Batununggal. IKM yang berada di wilayah ini tersebar di 7 Rukun Warga (RW) dan 7 Rukun Tetangga (RT). Adapun produk utama komoditi Industri TPT yang dibuat di sentra Binong Jati adalah pakaian berjenis sweater baik untuk pria, wanita, dan anak-anak yang dibuat dengan proses rajut. Adapun produk lainnya yang diproduksi adalah syal, aksesoris rajutan dan jenis pakaian lainnya. Berdasarkan hasil pengumpulan data, rekapitulasi IKM TPT yang ada di sentra Industri TPT Rajut Binong Jati diperlihatkan pada Tabel 1.

Tabel 1. Rekapitulasi data IKM TPT Binong Jati

\begin{tabular}{|c|c|c|c|}
\hline No & $\begin{array}{c}\text { Lokasi } \\
\text { (Rukun } \\
\text { Warga) }\end{array}$ & $\begin{array}{c}\text { Jumlah IKM } \\
\text { (Unit Usaha) }\end{array}$ & $\begin{array}{c}\text { Jumlah Tenaga } \\
\text { Kerja (Orang) }\end{array}$ \\
\hline 1 & RW 1 & 31 & 251 \\
\hline 2 & RW 2 & 49 & 298 \\
\hline 3 & RW 3 & 41 & 274 \\
\hline 4 & RW 4 & 126 & 1.027 \\
\hline 5 & RW 5 & 24 & 184 \\
\hline 6 & RW 6 & 14 & 66 \\
\hline 7 & RW 7 & 8 & 43 \\
\hline \multicolumn{2}{|c|}{ Total } & $\mathbf{2 9 3}$ & $\mathbf{2 . 1 4 3}$ \\
\hline
\end{tabular}

Selanjutnya dilakukan penilaian untuk setiap IKM di setiap Rukun Warga (RW). Pada bagian ini hanya akan dijelaskan mengenai survey pada satu RW, yaitu RW 1.

Berdasarkan hasil survey, terdapat 31 IKM TPT yang berfokus pada produksi sweater rajut di RW 1 ini. Dengan jumlah tenaga kerja sebanyak 251, rata-rata produksi swater yang dihasilkan selama satu tahun adalah 4.400 lusin dengan omset rata-rata Rp 120 juta. Sementara itu, hasil rata-rata penilaian IKM di lokasi ini adalah Bintang 2 dengan nilai total sebesar 70. Contoh penilaian yang dilakukan di RW 1 dapat dilihat pada Tabel 2 . 
Tabel 2 : Rekapitulasi Penilaian IKM RW 1

\begin{tabular}{|c|c|c|c|c|c|}
\hline $\begin{array}{l}\mathbf{N} \\
\mathbf{O}\end{array}$ & ASPEK PENILAIAN & $\begin{array}{l}\text { Nilai } \\
\text { Max }\end{array}$ & Penilaian & Gap & $\begin{array}{c}\text { Perlu } \\
\text { Perbaikan? }\end{array}$ \\
\hline A. & $\begin{array}{l}\text { ASPEK PRODUKSI, } \\
\text { PENGEMBANGAN PRODUK DAN } \\
\text { PENGEMBANGAN } \\
\text { MASYARAKAT }\end{array}$ & 36 & 28 & 8 & YA \\
\hline 1. & Aspek Produksi & 12 & 10 & 2 & \\
\hline a. & Sumber Bahan Baku Utama & 3 & 3 & 0 & TIDAK \\
\hline b. & Kapasitas Produksi (1 Tahun Terakhir) & 3 & 3 & 0 & TIDAK \\
\hline c. & Nilai Tambah Produksi & 3 & 2 & 1 & YA \\
\hline d. & Pengendalian Lingkungan & 3 & 2 & 1 & YA \\
\hline 2. & Aspek Pengembangan Produk & 12 & 9 & 3 & \\
\hline a. & $\begin{array}{l}\text { Pengembangan Model/Desain Produk } \\
1 \text { (satu) Tahun Terakhir }\end{array}$ & 3 & 3 & 0 & TIDAK \\
\hline b. & Inovasi dan Kreativitas Produk & 3 & 2 & 1 & YA \\
\hline c. & Penggunaan Teknologi & 3 & 2 & 1 & YA \\
\hline d. & Kemasan & 3 & 2 & 1 & YA \\
\hline 3. & Aspek Pengembangan Masyarakat & 12 & 9 & 3 & \\
\hline a. & Keberadaan Perusahaan di Sentra & 3 & 3 & 0 & TIDAK \\
\hline b. & Peran dalam Kelompok & 3 & 2 & 1 & YA \\
\hline c. & \begin{tabular}{|l|} 
Partisipasi dengan Masyarakat \\
\end{tabular} & 3 & 2 & 1 & YA \\
\hline d. & Pembukuan & 3 & 2 & 1 & YA \\
\hline B. & $\begin{array}{l}\text { ASPEK PEMASARAN DAN } \\
\text { RIWAYAT PRODUK } \\
\end{array}$ & 18 & 11 & 7 & YA \\
\hline 1. & Aspek Pemasaran & 12 & 7 & 5 & \\
\hline a. & Tujuan Pasar & 3 & 2 & 1 & YA \\
\hline b. & $\begin{array}{l}\begin{array}{l}\text { Peningkatan Omzet Penjualan } \\
\text { (dibandingkan tahun lalu) }\end{array} \\
\end{array}$ & 3 & 2 & 1 & YA \\
\hline c. & \begin{tabular}{|l|} 
Pelanggan \\
\end{tabular} & 3 & 2 & 1 & YA \\
\hline d. & Upaya Peningkatan Pemasaran & 3 & 1 & 2 & YA \\
\hline 2 & Aspek Riwayat Produk & 6 & 4 & 2 & \\
\hline a. & Riwayat Produk & 3 & 2 & 1 & YA \\
\hline b. & Kearifan Lokal & 3 & 2 & 1 & YA \\
\hline c. & $\begin{array}{l}\text { PEDOMAN PERTIMBANGAN } \\
\text { PADA JENIS DAN KUALITAS } \\
\text { PRODUK }\end{array}$ & 46 & 30 & 16 & YA \\
\hline 1. & Aspek Jenis Produk & 20 & 12 & 8 & \\
\hline a. & Produk dapat memperluas pangsa pasar & 4 & 0 & 4 & YA \\
\hline b. & $\begin{array}{l}\text { Bentuk (model/desain), warna, desain } \\
\text { sesuai dengan selera pasar }\end{array}$ & 4 & 4 & 0 & TIDAK \\
\hline
\end{tabular}

Analisis GAP dapat dilakukan setelah penilaian selesai dilakukan. Analisis ini dilakukan dengan menghitung selisih antara nilai penilaian dengan nilai max untuk aspek penilaian. Nilai max ini menggambarkan target atau harapan untuk aspek tersebut. Adapun berdasarkan hasil penilaian yang ditunjukkan pada Tabel 2, didapatkan hasil rata-rata penilaian IKM di lokasi ini adalah Bintang 2 dengan nilai total sebesar 70. Dapat dilihat juga pada hasil analisis gap bahwa IKM di lokasi ini masih perlu peningkatan dalam aspek nilai tambah produksi, pengendalian lingkungan, inovasi dan kreativitas produk, penggunaan teknologi, kemasan, peran dalam kelompok, partisipasi dengan masyarakat dan pembukuan. Sementara itu, fokus perbaikan secara menyeluruh harus dilakukan pada aspek pemasaran dan aspek kualitas produk. Perbaikan dan peningkatan secara konsisten dan menyeluruh pada aspek-aspek tersebut akan meningkatkan penilaian sentra ini. Penilaian ini dilakukan untuk seluruh RW, yaitu RW 1 hingga RW 7.

Berdasarkan nilai yang diperoleh dari setiap RW tersebut, maka rekapitulasi seluruh IKM yang berada di sentra Industri TPT Rajut Binong Jati adalah Bintang 3 artinya kualitas IKM sudah cukup baik.
Apabila dilakukan beberapa perbaikan, maka IKM tersebut dapat mencapai Bintang 4 dan dapat masuk ke pasar nasional secara luas dan pasar internasional. Adapun rekapitulasi perhitungan untuk setiap lokasi survey berdasarkan kecamatan diperlihatkan pada Tabel 3. Analisis gap yang dilakukan untuk setiap RW kemudian digabungkan sesuai dengan indicator kondisi IKM. Rekapitulasi Penilaian GAP dapat dilihat pada Tabel 4.

Tabel 3 : Rekapitulasi sentra IKM

\begin{tabular}{|c|c|c|c|}
\hline No & Lokasi & Nilai & Kesimpulan \\
\hline 1 & RW 1 & 70 & Bintang $2^{* *}$ \\
\hline 2 & RW 2 & 70 & Bintang 2 \\
\hline 3 & RW 3 & 72 & Bintang 3 \\
\hline 4 & RW 4 & 73 & Bintang 3 \\
\hline 5 & RW 5 & 74 & Bintang 3 \\
\hline 6 & RW 6 & 68 & Bintang 2 \\
\hline 7 & RW 7 & 69 & Bintang 2 \\
\hline \multicolumn{2}{|c|}{ Rata } \\
\hline
\end{tabular}

Tabel 4 Rekapitulasi Penilaian IKM

\begin{tabular}{|c|l|c|c|c|c|}
\hline No & \multicolumn{1}{|c|}{ ASPEK PENILAIAN } & $\begin{array}{c}\text { Nila } \\
\text { i } \\
\text { Max }\end{array}$ & Penilaian & Gap & $\begin{array}{c}\text { Perlu } \\
\text { Perbaikan } \\
\boldsymbol{?}\end{array}$ \\
\hline A. & $\begin{array}{l}\text { ASPEK PRODUKSI, } \\
\text { PENGEMBANGAN PRODUK } \\
\text { DAN PENGEMBANGAN } \\
\text { MASYARAKAT }\end{array}$ & $\mathbf{3 6}$ & $\mathbf{2 8}$ & $\mathbf{1 1}$ & YA \\
\hline 1. & Aspek Produksi & 12 & 9 & 3 & \\
\hline a. & Sumber Bahan Baku Utama & 3 & 3 & 0 & TIDAK \\
\hline b. & $\begin{array}{l}\text { Kapasitas Produksi (1 Tahun } \\
\text { Terakhir) }\end{array}$ & 3 & 3 & 0 & TIDAK \\
\hline c. & Nilai Tambah Produksi & 3 & 2 & 1 & YA \\
\hline d. & Pengendalian Lingkungan & 3 & 2 & 1 & TIDAK \\
\hline 2. & Aspek Pengembangan Produk & 12 & 8 & 4 & \\
\hline a. & $\begin{array}{l}\text { Pengembangan Model/Desain } \\
\text { Produk 1 (satu) Tahun Terakhir }\end{array}$ & 3 & 3 & 0 & TIDAK \\
\hline b. & Inovasi dan Kreativitas Produk & 3 & 3 & 0 & TIDAK \\
\hline c. & Penggunaan Teknologi & 3 & 2 & 1 & YA \\
\hline d. & Kemasan & 3 & 2 & 1 & YA \\
\hline 3. & $\begin{array}{l}\text { Aspek Pengembangan } \\
\text { Masyarakat }\end{array}$ & 12 & 8 & 4 & \\
\hline a. & Keberadaan Perusahaan di Sentra & 3 & 3 & 0 & TIDAK \\
\hline b. & Peran dalam Kelompok & 3 & 2 & 1 & YA \\
\hline c. & Partisipasi dengan Masyarakat & 3 & 1 & 2 & YA \\
\hline d. & Pembukuan & 3 & 2 & 1 & YA \\
\hline B. & $\begin{array}{l}\text { ASPEK PEMASARAN DAN } \\
\text { RIWAYAT PRODUK }\end{array}$ & 18 & 12 & 7 & YA \\
\hline 1. & Aspek Pemasaran & 12 & 7 & 5 & \\
\hline a. & Tujuan Pasar & 3 & 2 & 1 & YA \\
\hline b. & $\begin{array}{l}\text { Peningkatan Omzet Penjualan } \\
\text { (dibandingkan tahun lalu) }\end{array}$ & 3 & 2 & 1 & YA \\
\hline c. & Pelanggan & 3 & 2 & 1 & YA \\
\hline d. & Upaya Peningkatan Pemasaran & 3 & 2 & 1 & YA \\
\hline 2 & Aspek Riwayat Produk & 6 & 4 & 2 & \\
\hline a. & Riwayat Produk & 3 & 2 & 1 & YA \\
\hline b. & Kearifan Lokal & 3 & 2 & 1 & YA \\
\hline C. & $\begin{array}{l}\text { PEDOMAN PERTIMBANGAN } \\
\text { PADA JENIS DAN KUALITAS } \\
\text { PRODUK }\end{array}$ & 46 & 31 & 16 & YA \\
\hline 1. & Aspek Jenis Produk & 20 & 12 & 8 & \\
\hline & & & & \\
\hline
\end{tabular}

Setelah seluruh data berhasil dikumpulkan, langkah selanjutnya adalah melakukan 
analisis SWOT untuk Sentra IKM Industri TPT Rajut Binong. Berdasarkan analisis SWOT, didapatkan identifikasi strengths, weakness, opportunities dan threats untuk Sentra IKM Industri TPT Rajut Binong Jati adalah sebagai berikut:

- Strengths:

- S1: Memiliki pengalaman panjang dalam produksi industri rajut

- S2: Memiliki kualitas produk yang diakui level lokal dan nasional

- S3: Transportasi ke lokasi mudah dijangkau

- S4: Adanya Kelompok IKM sebagai pusat informasi

- S5: Kompetensi SDM cukup baik

- S6: Masih ada IKM yang mampu bertahan

- Weakness :

- W1: UPT belum optimal

- W2: Teknologi Pemesinan masih manual, hasil kurang efektif dan tidak efisien.

- W3: Tidak adanya supplier bahan baku di dalam sentra

- W3: Standarisasi proses masih sangat kurang

- Opportunities:

- 01: Kepedulian pemerintah dalam pengembangan IKM, baik Pusat maupun Daerah

- O2: Masih besarnya pasar produk Industri TPT Rajut nasional maupun internasional

- O3: Terus meningkatnya kebutuhan Industri TPT nasional seiring dengan penigkatan kebutuhan masyarakat.

Threats:

- T1: Persaingan industri lokal dan internasional (MEA)

- T2: Tata ruang sentra yang semakin padat dan belum tertata

- T3: Peningkatan harga bahan baku dan operasional lainnya

- T4: Berkurangnya minat SDM untuk bekerja di sentra khususnya IKM rajut

\subsection{Sistem Informasi Berbasis Web}

Untuk menggambarkan kaitan antara data, pada penelitian ini digunakan diagram entity relationship. Diagram ini berisi komponen-komponen himpunan entitas dan himpunan relasi masing-masing modul yang merepresentasikan seluruh fakta dari dunia nyata. Adapun aplikasi sistem informasi berbasis web yang dibuat menampilkan statistik IKM, profil sentrasentra, profil industri-industri Kecil dan Menengah, profil industri pendukung, serta agenda acara.

Untuk membuka website Sistem Informasi Berbasis Web, yang harus dilakukan pertama kali adalah membuka browser, dan ketikan alamat url pada kolom yg tersedia dengan http://www.monev.ti.unpas.ac.id, maka akan muncul tampilan seperti pada Gambar 2.

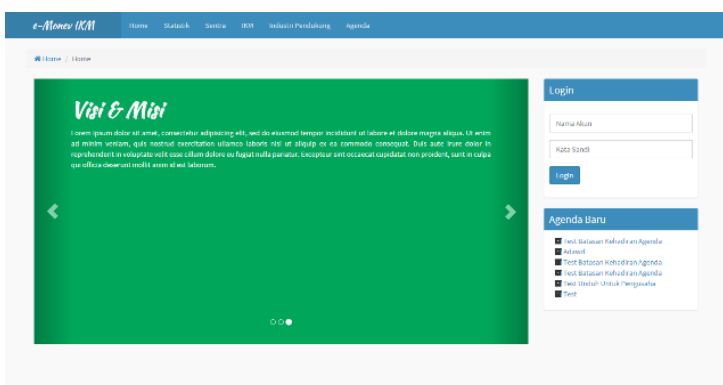

Gambar 2. Tampilan antar muka website monev IKM

\section{Kesimpulan}

Kesimpulan yang dihasilkan dari penelitian ini adalah:

1. Berdasarkan hasil pengumpulan dan pengolahan data, diketahui bahwa jumlah IKM Industri TPT di sentra Industri Rajut Binong Jati yang teridentifikasi berjumlah 293 Unit Usaha yang menyerap 2.143 tenaga kerja.

2. Berdasarkan penilaian sentra, rata-rata IKM Industri TPT di sentra Industri Rajut Binong Jati mendapatkan klasifikasi Bintang 2.

3. Berdasarkan Analisis Gap, terdapat beberapa hal yang perlu diperbaiki dalam pengembangan sentra yaitu:
(a). Perbaikan teknologi;
(b). Pemberdayaan kembali Asosiasi;
(c). Penerapan standar-standar proses; 
(d). Peningkatan inovasi dan kreatifitas SDM dalam Kearifan Lokal;

(e). Kemasan Produk dan (f). Manajerial usaha

4. Berdasarkan Analisis SWOT, terdapat beberapa hal yang telah teridentifikasi sebagai kondisi eksisting IKM dalam Sentra Industri Rajut Binong Jati. yaitu:

- Strengths:

- S1: Memiliki pengalaman panjang dalam produksi industri rajut

- S2: Memiliki kualitas produk yang diakui level lokal dan nasional

- S3: Transportasi ke lokasi mudah dijangkau

- S4: Adanya Kelompok IKM sebagai pusat informasi

- S5: Kompetensi SDM cukup baik

- S6: Masih ada IKM yang mampu bertahan

- Weakness :

- W1: UPT belum optimal

- W2: Teknologi Pemesinan masih manual, hasil kurang efektif dan tidak efisien.

- W3: Tidak adanya supplier bahan baku di dalam sentra

- W3: Standarisasi proses masih sangat kurang

Opportunities :

- 01: Kepedulian pemerintah dalam pengembangan IKM, baik Pusat maupun Daerah

- O2: Masih besarnya pasar produk Industri TPT Rajut nasional maupun internasional

- O3: Terus meningkatnya kebutuhan Industri TPT nasional seiring dengan penigkatan kebutuhan masyarakat.

- Threats :

- T1: Persaingan industri lokal dan internasional (MEA)

- T2: Tata ruang sentra yang semakin padat dan belum tertata

- T3: Peningkatan harga bahan baku dan operasional lainnya

- T4: Berkurangnya minat SDM untuk bekerja di sentra khususnya IKM rajut

5. Dihasilkannya sebuah Sistem Informasi berbasis web yang dapat dipergunakan oleh stakeholder sentra IKM Tektil dan Produk Tekstil (TPT) di Provinsi Jawa
Barat yang berguna untuk updating data IKM, analisis aktivitas IKM, sekaligus tempat pertukaran informasi stakeholder sentra.

\section{DAFTAR PUSTAKA}

Arthurs, David, Erin Cassidy, Charles $\mathrm{H}$. Davis, 2009, Indicators to support innovation cluster policy, Int. J. Technology Management, Vol. 46, No. $3 / 4$.

Davis. B. Gordon, 2005, Sistem Informasi Manajemen, Edisi 2 Revisi, PPM, Indonesia

Direktorat Jenderal Industri Kecil Menengah Kementerian Perindustrian, 2012, Petunjuk Teknis Penilaian, Klasifikasi dan Pembinaan Produk OVOP

Djunid, Amsal, 2008, Manajemen Proyek Pengembangan Sistem. Tesis S2, Yogyakarta.

E. Burton Swanson \& Neil C. Ramiller, 2004, Innovating Mindfully with Information Technology, MIS Quarterly, Vol. 28 No. 4 pp. 553-583

Frenzel, Carroll W, 1996, Management of Information Technology, Boyd \& Fraser Publishing Company, USA

Henderi, 2006, Unified Modelling Language, Raharja Enrichment Centre (REC), Tangerang

Irawati, Dessy, 2007, Strengthening Cluster Building in Developing Country alongside the Triple Helix: Challenge for Indonesian Cluster - A Case Study of the Java Region, MPRA Paper No. 5831, Munich

James A, O'Brien, 2005, Introduction to Information Systems, terjemahan oleh Dewi Fitriasari, Salemba Empat, Jakarta

Japan International Cooperation Agency (JICA), 2004, The Study on Strengthening Capacity of SMEs Clusters in Indonesia, Jakarta

Jogiyanto HM, 1990, Analisis \& Desain Sistem Informasi : Pendekatan Terstruktur : Teori dan Praktek Aplikasi Bisnis, Andi Offset, Yogyakarta

Laudon, Kenneth C.; Jane P. Laudon, 2000, Management Information Systems, organization and Technology in The Networked Enterpise", PrenticeHall, New Jersey, USA

Laudon, Kenneth C, Jane, 2008, Sistem Informasi Manajemen, Buku 1 edisi 10, Salemba Empat, Jakarta 
Leman, 1997, Metodologi Pengembangan Sistem Informasi, PT. Elex Media Komputindo, Jakarta

Lapointe, Liette, Suzanne Rivard, 2005, A Multilevel Model of Resistance to Information Technology Implementation, MIS Quarterly, Vol. 29 No. 3, pp. 461-491

Nugroho, Adi, 2005, Analisis dan Perancangan Sistem Informasi dengan Metoda Berorientasi Objek. Edisi Revisi, Informatika, Bandung

Porter, M. E., 2000, The Competitive Advantage of Nations, Macmillan, London

Rahardja, Untung, 2007, Analisis Kelayakan Investasi Digital Dashboard pada Manajemen Akademik Perguruan Tinggi: Studi Kasus pada Perguruan Tinggi Raharja, Thesis, Program Studi Magister Teknologi Informasi, Fakultas IImu Komputer, Universitas Indonesia

Usman, Husaini, 2006, Manajemen: Teori, Praktik dan Riset Pendidikan, PT Bumi Aksara, Jakarta

Wahyuniardi, Rizki dkk., 2014, Penyusunan Sistem Informasi Berbasis Web untuk Monitoring dan Evaluasi IKM Alas Kaki di Cibaduyut-Jawa Barat. Prosiding Seminar Nasional Teknik Industri BKSTI 2014, pp. 6: 25 - 30

Wahyuniardi, Rizki dkk., 2015, Penyusunan Sistem Informasi Berbasis Web untuk Monitoring dan Evaluasi Klaster Industri Kecil dan Menengah di Jawa Barat. Prosiding Seminar Nasional Pengkajian dan Penerapan Teknologi 2015
Wahyuniardi, Rizki dkk., 2015, Sistem Informasi Berbasis Web untuk Monitoring dan Evaluasi Sentra Industri Kecil di Jawa Barat. Jurnal IImiah Teknik Industri UMS, Vol. 14 No.2 Des 2015

Wahyuniardi, Rizki dkk., 2016, Pembangunan Sistem Informasi Berbasis Web untuk Monitoring dan Evaluasi Sentra Industri Kecil dan Menengah di Jawa Barat. Jurnal IImiah Teknik Industri UNTAR, Vol. 4 No.1 Feb 2016 